\title{
Medical waste and health workers in Gaza governorates
}

H.T.N. Massrouje ${ }^{1}$

$$
\begin{aligned}
& \text { الماملون المهيحيرن والفضلالت الطبة في محانظات غزة }
\end{aligned}
$$

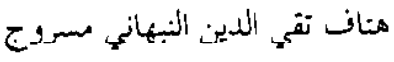

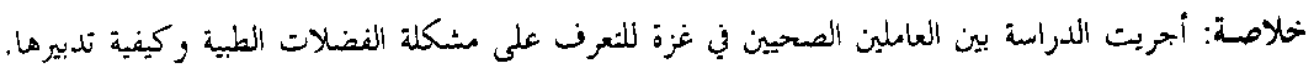

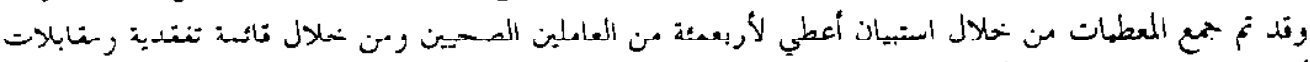

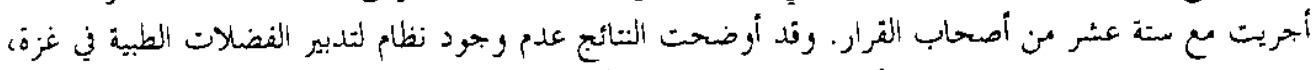

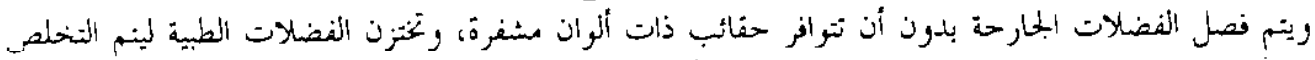

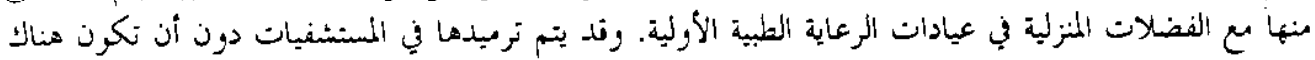

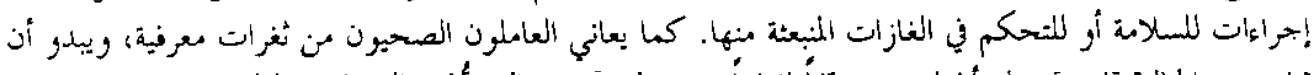

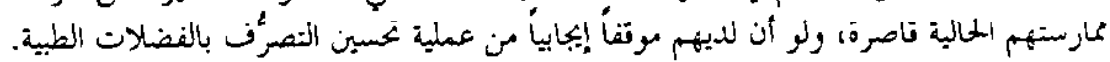

ABSTRACT The study was conducted among health workers in Gaza to identify and highlight the problem of medical waste management. Data were collected through a questionnaire (given to 400 health workers), a checklist and interviews (with 16 decision-makers). Results show that there is no system for medical waste management in Gaza. Segregation is done only for sharps and there are no colour-coded bags. Medical waste is stored and disposed of with domestic waste in primary health care cliricis an id is incinerated in hospitals, but there are no emission control or safety measures. There are some gaps in knowledge of health care workers, and current practices are inadequate. However there is generaily a positive attitude to improving medical waste management among thoso curvoyod and intorviowed. A national programme for medical waste management is essential in Palestine.

\section{Les déchets médicaux et les agente de aanté dane loe gouvornorate do Gaza}

RESUME L'étude a été réalisée auprès des agents de santé à Gaza pour identifier et mettre en évidence le problème de la gestion des déchets médicaux. Des données ont été recueillies au moyen d'un questionnaire (distribué à 400 agents de santé). d'une liste de référence et d'entrevues (avec 16 responsables). Les résultats montrent qu'il n'existe pas de système pour la gestion des déchets médicaux à Gaza. Le tri sélectif n'est effectué que pour les objets piquants ou tranchants et il n'y a pas de sacs de différente couleur déterminée selon la nature des déchets. Les déchets médicaux sont stockés et éliminés avec les déchets domestiques dans les établissements de soins de santé primaires et sont incineres dans les hōpitaux, mais il n'y a pas de contrôle des émissions ni de mesures de sécurité. II existe certaines lacunes dans les connaissances des agents de santé, et les pratiques courantes sont inadéquates. Toutefois, il y a de manlère générale une attitude pusitive vis-à-vis de l'amélioration de la gestion des déchets módicaux parmi les personnes interrogées dans le cadre de l'étude. 11 est indispensable de mettre en place un programme national de gestion des déchets médicaux en Palestine.

'School of Public Health, Al Quads University, Ministry of Health, Palestinian National Authority, Gaza, Palestine.

Received: 19/03/01; accepted: 08/07/01

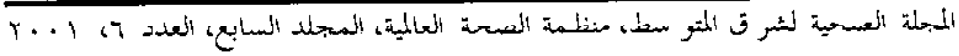




\section{Introduction}

Medical waste is a public health issue that attracts attention in both industrialized and developing countries. Certain categories of medical waste are among the most hazardous and potentially dangerous of all the waste arising in the community [l]. Improper management of medical waste may pose health hazards through transmission of diseases, not only to health workers and their families, but to patients and their relatives, especially children whose play activity and mouthing behaviour increases their contact with medical waste, thus exposing them to injuries and infections [2]. Discarded drugs may be collected from clinic rubbish and may be sold or consumed without professional advice [3]. Waste from radioactive isotopes and genotoxic treatment may cause health risks and severe injury [4]. In addition to health hazards, environmental hazards have to be considered, such as the contamination of soil and groundwater and poisonous emissions from improper burning of medical waste [3].

In the long term, medical waste can not only impair the quality of life of the community, but can also affect the welfare of the entire population and the national econ omy.

Until the early 1980s, there was little interest in medical waste but in 1987 concern over medical waste dominated the media in the United States of America [5]. In Palestine, concern about medical waste is recent and is still not as great as it should be. This may be attributed to political, social and economic reasons. This study assessed medical waste management in governmental institutions in Gaza in order to help identify the problems and assist the planning of an appropriate medical waste management system.

\section{Methods}

The study was carried out in governmental institutions in Gaza after formal approval from the Director-General of the Ministry of Health, Data were gathered through a questionnaire, in-depth interviews and an observational checklist. Sampling was random according to a sampling plan that allocated representative facilities in five districts. In all, 5 hospitals (different departments) and 11 primary health care (PHC) clinics were surveyed.

Questionnaire forms were distributed to 400 health workers and the response rate was $65 \%$. Health workers should have a minimum level of knowledge about medical Indters, especially medical waste, and therefore the same questions were asked to different categories of health workers: physicians, nurses, paramedical staff and ancillary workers. The questions were arranged in four sets aimed at assessing: background of lie health worker; his/her general knowledge about medical waste in terms of constituents, hazards and diseases that could be transmilled as a result of improper management of medical waste; attitudes towards segregation, incineration, training courses, dcvelopnent of a medical waste management system and the current situation; and practices about collection, trunsport, storage and dispusal. Current management practices of medical waste were also observed and entered on a checklist which included sources and type of waste generated in different centres, method of collection, transport, storage and disposal, specifically incinelation and the condition of incinerators.

Interviews were conducted with 16 decision-makers in different ministries concerned with medical waste. They were asked questions about the current situation, 
obstacles they faced, coordination between ministries and their suggested strategies for developing a system for the management of medical waste.

Statistical analysis was carried out using SPSS for two sources of data, the questionnaire and checklist. Frequencies and percentages were calculated in both models. Chi-squared was used to find out associations of three categories of knowledge (high, medium and low) with profession, work area, duration of employment in the current place, previous experience outside Gaza, presence of instructions and training courses. $P<0.05$ was considered significant.

Interviews were reviewed and helped highlight the problem and suggest a strategy for medical waste management in Gaza.

\section{Results}

Results of the study show that the medical waste produced in health care facilities includes sharps, infectious, pathological, chemical, pharmaceutical and radioactive waste, and pressurized containers. Partial segregation for sharps was observed in $89.5 \%$ of the places (Table 1 ); $78.6 \%$ were collected in special sharp boxes donated by the World Health Organization. Transport of medical waste was made in thin plastic bags and there were no colour-coded bags. The same kind and colour of domestic waste bags is used for medical waste. There were generally no storage places; in PHC centres medical waste was stored with domestic waste and in hospitals it is stored in the outdoors near incinerators. As for disposal, medical waste was disposed of with domestic waste in PHC clinics where municipality trucks collect medical and non-medical waste together. In some clinics it was burned manually in the open
Table 1 Comparison of observed and reported practices of medical waste

\begin{tabular}{lcc}
\hline Practice & $\begin{array}{c}\text { Observed } \\
\%\end{array}$ & $\begin{array}{c}\text { Reported } \\
\%\end{array}$ \\
\hline Collection & & \\
$\quad$ Segregation: sharps & 89.5 & 65 \\
$\quad$ Colour coding bags & 0 & 13.2 \\
Transport & & \\
$\quad$ Plastic bags & 97.4 & 58.5 \\
Containers & 0 & 18.1 \\
$\quad$ venicles & & 7.5 \\
Storage & & \\
$\quad$ Special containers & 65.0 & 56.5 \\
$\quad$ Domestic waste & 31.6 & 23.5 \\
Disposal & & \\
$\quad$ Domestic waste & 23.7 & 24.6 \\
$\quad$ Landflll & 2.6 & 7.9 \\
$\quad$ Special incinerator & 39.4 & 15.3 \\
\hline
\end{tabular}

air. In hospitals, it was incinerated but without any control or protection measures for workers. Liquid medical waste was disposed of in the same pipelines as domestic waste.

As regards knowledge of medical waste, $87 \%$ of the study group declared that they knew ahout medical waste. Table 2 shows knowledge of the health workers as regards the constituents of medical waste and the hazard categories into which the different types fall. Profession was highly associated with knowledge of constituents. hazard categories and the occupational hazards of medical waste $(P<$ 0.05 ). Duration of employment was not associated with knowledge of the constituents of medical waste but was associated with knowledge of the hazard categories and occupational hazards $(P<0.05)$. Previous experience outside Gaza, the presence of instructions and previous training courses were not associated with greater knowl-

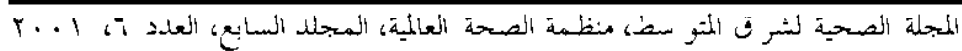




\begin{tabular}{lcc}
\hline $\begin{array}{l}\text { Table } 2 \text { Distribution of the study group according to their knowledge of } \\
\text { the constituents and hazard categories of medical waste }\end{array}$ \\
\hline $\begin{array}{l}\text { Type of waste } \\
\text { whowledge as to } \\
\text { wher it is a constituent } \\
\text { of medical wacto } \\
\%\end{array}$ & $\begin{array}{c}\text { Knowledge of the } \\
\text { the hazard category }\end{array}$ \\
\hline $\begin{array}{l}\text { Paper, cartoon, boxes } \\
\text { (not medlcal waste) }\end{array}$ & 54.2 & 83.1 \\
Sharps & 83.8 & 89.2 \\
Dressings, cotton, & & \\
plasters & 69.8 & 51.5 \\
Chemicals & 51.9 & 68.8 \\
Radioactive material & 35.8 & 61.5 \\
Pathology material & 54.2 & 60.4 \\
Pharmaceuticals & 63.5 & 60.8 \\
Body fluids & 0.5 & 76.5 \\
Cultures & 46.9 & 59.2 \\
Pressurized containers & 27.3 & 25.8 \\
Kitchen waste & & 85.0 \\
(not medical waste) & 74.2 & \\
\hline
\end{tabular}

edge. There was also no difference in the knowledge of workers from private companies and governmental workers.

About $70.0 \%$ of the participants knew that they were exposed to oecupational hazards as a result of improper management of medical waste. Table 3 shows the knowledge of the participants as regards the sources of exposure to medical waste. As for knowledge of transmitted diseases, $55.8 \%$ knew that viral hepatitis and $28.5 \%$ knew that HIV infection could be transmitted as a result of the improper management of medical waste. Concerning environmental hazards, $96.0 \%$ of the medical workers knew that medical waste could pollute the environment and $73.5 \%$ knew of the presence of incinerators in Gaza.

Attitudes in general were positive. Table 4 shows the participants' attitudes towards instructions, previous training courses that were given, the need for waining, and the development of a medical waste management system. Opinions of the current situation are shown in Table 5. These was anl association between profession and opinion of the current situation and this was statistically significant $(P<0.05)$.

Jable 3 Distribution of the study group according to their knowledge of sources of occupational hazards

\begin{tabular}{lr}
\hline Source of hazard & $\%$ \\
\hline Needle stick injury & 46.2 \\
Body fluids & 20.0 \\
Chemicals & 8.5 \\
Radiation & 3.8 \\
\hline
\end{tabular}


Table 4 Attitudes towards instructions, previous training courses, need for training and development of a medical waste management system

\begin{tabular}{lrrrc}
\hline Attitude & Instructions & $\begin{array}{c}\text { Training } \\
\text { courses }\end{array}$ & $\begin{array}{c}\text { Need for } \\
\text { training }\end{array}$ & $\begin{array}{c}\text { Need for developing a } \\
\text { medical waste } \\
\text { management system }\end{array}$ \\
\hline Very important & 90.5 & 80.8 & 96.9 & 96.0 \\
Fairly important & 8.7 & 13.5 & 1.9 & - \\
Not important & 0.8 & 5.7 & 1.2 & 4.0 \\
\hline
\end{tabular}

The study group were asked for sug gestions for the development of medical waste management. The most frequent suggestions were for raising awareness, provision of the necessary supplies and facilities to allow segregation of medical waste to be carried out, colour-coding, landfills and recycling.

As regards practices, there were two sources of data; observed through the checklist described at the beginning of the article and reported through the questionnaire. Table 1 shows a comparison of reported and observed practices.

In interviews with stakeholders, all agreed that there was a lack of a proper

Table 5 Opinions of the medical workers of the current situation concerning medical waste disposal according to profession

\begin{tabular}{|c|c|c|c|c|}
\hline Profession & $\begin{array}{c}\text { Excellent } \\
\%\end{array}$ & $\begin{array}{c}\text { Good } \\
\%\end{array}$ & $\begin{array}{c}\text { Acceptable } \\
\%\end{array}$ & $\begin{array}{c}\text { Poor } \\
\%\end{array}$ \\
\hline Physician & 1.8 & 17.9 & 26.8 & 53.5 \\
\hline Nurse & 1.5 & 19.7 & 39.4 & 39.4 \\
\hline $\begin{array}{l}\text { Paramedical } \\
\text { staft }\end{array}$ & 1.9 & 11.1 & 35.2 & 51.8 \\
\hline $\begin{array}{l}\text { Ancillary } \\
\text { Worker }\end{array}$ & 17.2 & 39.7 & 32.8 & 10.3 \\
\hline
\end{tabular}

$\chi^{2}=51.4, \mathrm{P}<0.05$ system of medical waste management, and most of them were dissatisfied with the current practices. The participants identified several needs. Raising awareness was the most frequently cited. The obstacles faced were lack of a proper system, lack of awareness, lack of funding, lack of training and lack of coordination among different ministries. All agreed on the need for formulating rules and guidelines for medical waste and they suggested strategies for overcoming the obstacles.

\section{Discussion}

The results of the study make it difficult to draw firm conclusions because of the wide range of issues addressed and the reliance on the response of health workers of different catcgorics. Thus a combination of reported answers through a self-administered questionnaire, an observational checklist and in-depth interviews were used.

Only $65 \%$ of the study group responded to the questionnaire. Those who participat ed can be expected to have better standards than those who did not participate. The high level of knowledge of sharps as con stituents of medical waste, the hazard category of medical waste and medical waste as an occupational hazard may be duc to 
the familiarity of health workers with syringes and needles and with accidents that happen as a result of sharps injury [6-8]. Knowledge of exposure to occupational hazard reported was lower $(70.4 \%)$ than in Egypt (92.9\%) [9]. Also knowledge of diseases that could to be transmitted as a result of improper management of medical waste reported was lower [viral hepatitis $(55.8 \%)$ and HIV infection (28.5\%)] than in Egypt [hepatitis B $(90.3 \%)$, HIV infection (73.2\%)] [10]. This lower awareness of our group may result from political and social reasons. Also the lower knowledge of HIV than HBV in this study might be due to the awareness of our study group that $\mathrm{HIV}$ is much less infective and much less prevalent than $\mathrm{HBV}$.

Knowledge of chemicals and radiation as sources of occupational hazard was low and this might put health workers at risk. The participants appeared to have the greatest knowledge about environmental hazards. This may be due to the spread of environmental pollutants in Gaza, which has made health workers familiar with pollution.

Looking at the factors that affected knowledge, locality did not play a role, perhaps because Gaza is a small area and thus differences in knowledge between the governorates are not obvious. Profession was highly associated with knowledge, which might indicate that the main source of knowledge of the study group was from their study courses, while training courses had limited impact as shown by the finding that previous training courses and the presence of instructions made no statistically significant difference to knowledge. The highest level of knowledge of hazard categories of medical waste was among those who had worked for a moderate length of time (2-5 years). This may be attributed to the fact that concern about medical waste is recent in our part of the world. As for occupational hazards, the highest level of knowledge was found in those who had worked for more than 10 years and lowest for newly employed staff members. This might indicate that personnel gain experience about occupational hazards from accidents that happen in their daily work.

The positive attitudes reported indicate the good intentions of the target population to modify practices. Attitudes towards instructions, need for training and the development of a medical waste management system were positive. Attitudes towards the current situation were generally negative, which indicates that the study group are dissatisfied with the current situation. Participants were most concerned about gaining knowledge through training courses, instructions and the provision of necessary supplies and facilities. Thus people have the intention to improve if they are provided with the knowledge and the means.

There was a difference between reported and observed practices. The reason for the difference is not clear, but a possible explanation is that people might not tell the truth to try and focus attention on the problem, or conversely, to give a better impression.

In PHC clinics, domestic waste bins were used for large proportions of medical waste. Anderson warned against mixing domestic waste with medical waste as it acts as a breeding ground for bacteria [I]]. The current situation in Gaza may be due to inaccessibility of facilities for medical waste handling.

Incineration is the main route for medical waste disposal. In some PHC clinics part of the medical waste was incinerated manually outdoors and in hospitals it was incinerated in hospital incinerators. Incineration is the recommended method in 
many studies [2,12]. However, incineration has adverse effects on the environment [13] and the reliability of incinerators has to be considered [14]. It was observed that the temperature of incineration did not comply with standard operation [15] and ashes were collected manually without protective devices, which does not comply with Environmental Protection Agency [16] or World Health Organization [4] standards.

Results of the interviews indicate that decision-makers are aware of the problem, but obstacles, mainly the lack of a medical waste disposal system, limit their responsibilities and increase the complexity of the problem. They suggested different strategies, which should be useful for formulating a strategy for medical waste management in Gaza.

\section{Conclusion}

The study revealed that medical waste in Gaza is not given sufficient priority or concern. There is no system of medical waste management, a lack of necessary supplies and facilities, a lack of knowledge among health workers and a lack of coordination among different ministries. The following actions are therefore recommended.

- Establishment of an authorized directorate responsible for all aspects of medical waste management. Its main function should be the creation of a national programme containing uniform requirements for medical waste handling and disposal.

- Coordination between different ministries concerned with medical waste.

- Provision of adequate supplies and facilities needed for medical waste handling, such as colour-coded bags, puncture-proof boxes, special trucks for medical waste transport and protective devices.

- Provision of health education, not only for health workers but for all the community, about the hazards of medieal waste and how to minimize them.

- Sensitization of international agencies and donors to atrract funds for medical waste management.

- Encouragement of studies on different aspects of medical waste, such as the creation of database information in different sectors, risk analysis and disposal methods.

\section{References}

1. Medical waste committee, air and waste management association. Medical waste disposal: report of the medical waste committee (Wt-3), technical council. Air waste, 1994, 44:1176-9.

2. Johnson B. Impact of hazardous waste on human health. Washington $\mathrm{DC}$, Lewis Publishers, 1999.

3. Halbwachs $H$. Solid waste disposal in district health facilities. World health forum, 1994, 85:583-9.
4. Pruss A, Giroult E, Rushbrook P. Safe management of wastes from health-care activities. Geneva, World Health Organization, 1999.

5. Furr $\mathrm{K}$, ed. CRC handbook of laboratory safety, 4th ed. London, GRC Press, 1995.

6. Liss $\mathrm{G}$ el al. Improper office disposal of needles and other sharps: an occupational hazard outside of health care insti- 
tutions. Canadian journal of public health, 1990, 81(6):417-20.

7. Jagger $J$ et al. Rates of needle-stick injuries caused by various devices in a university hospital. New England journal of medicine, 1983, 319(5):284-8.

8. Nixon A et al. Simple device to prevent accidental needle-prick injuries. Lancet, 1986, 1(8486):888-9.

9. Nessim D. Health education on hospital wasto management among health care workers [Master thesis]. Cairo, Egypt, Ain Shams University, 1996.

10. El-Ayat S. Health hazaras among nospttal workers [Master thesis]. Cairo, Egypt, Ain Shams University, 1994.

11. Anderson G. Clinical waste disposal, Amman, Jordan, World Health Organization, 1992.
12. Horvath A. Egeszsegugyi intezmenyekben keletkezo hulladekok kezelese. [Management of waste disposal in medical institutions.] Orvosi-hetilap, 1991 , 132(17):919-24

13. Environmental and occupational risks of health care. London, British Medical Association, 1994.

14. Thornton $T$ et al. Dioxin prevention and medical waste incinerators. Public hoalth roports, 1996, 111(4):208-308.

15. Operating instruction book. Kalfrisa pyrolytic static furnace PS-2. Zaragoza, Spain, Kalfrisa, 1994 (Ref 94-1027).

16. Handbook: operation and maintenance of hospital medical waste incinerators. New York, Environmental Protection Agency, 1990.

Improvements in nealth-care waste management rely on the following key elements:

- The build-up of a comprehensive system, addressing respon sibilities, resource allocation, handling and disposal. This is a long-term process, sustained by gradual improvements;

- Awareness raising and training about risks related to healthcare waste, and safe and sound practices;

- Selection of safe and environmentally-friendly management options, to protect people from hazards when collecting, handing, storing, transporting, treating or disposing of waste.

Government commitment and support is needed to reach an overall and long-term improvement of the situation, although immediate action can be taken locally. Health-care waste management is an integral part of health-care, and creating harm through inadequate waste management reduces the overall benefits of health-care.

Source: Wastes from health-care activities. WHO Fact sheet No. 253, October 2000 